\title{
Major soluble proteome changes in Deinococcus deserti over the earliest stages following gamma-ray irradiation
}

Alain Dedieu ${ }^{1 *}$, Elodie Sahinovic ${ }^{1}$, Philippe Guérin ${ }^{1}$, Laurence Blanchard ${ }^{2,3,4}$, Sylvain Fochesato ${ }^{2,3,4}$, Bruno Meunier ${ }^{5}$, Arjan de Groot ${ }^{2,3,4}$ and Jean Armengaud ${ }^{1}$

\begin{abstract}
Background: Deinococcus deserti VCD115 has been isolated from Sahara surface sand. This radiotolerant bacterium represents an experimental model of choice to understand adaptation to harsh conditions encountered in hot arid deserts. We analysed the soluble proteome dynamics in this environmentally relevant model after exposure to 3 kGy gamma radiation, a non-lethal dose that generates massive DNA damages. For this, cells were harvested at different time lapses after irradiation and their soluble proteome contents have been analysed by 2-DE and mass spectrometry.

Results: In the first stage of the time course we observed accumulation of DNA damage response protein DdrB (that shows the highest fold change $\sim 11$ ), SSB, and two different RecA proteins (Rec $A_{p}$ and Rec $A_{C}$ ). Induction of DNA repair protein PprA, DNA damage response protein DdrD and the two gyrase subunits (GyrA and GyrB) was also detected. A response regulator of the SarP family, a type II site-specific deoxyribonuclease and a putative $\mathrm{N}$-acetyltransferase are three new proteins found to be induced. In a more delayed stage, we observed accumulation of several proteins related to central metabolism and protein turn-over, as well as helicase UvrD and novel forms of both gyrase subunits differing in terms of isoelectric point and molecular weight.

Conclusions: Post-translational modifications of GyrA ( $\mathrm{N}$-terminal methionine removal and acetylation) have been evidenced and their significance discussed. We found that the Deide_02842 restriction enzyme, which is specifically found in $D$. deserti, is a new potential member of the radiation/desiccation response regulon, highlighting the specificities of $D$. deserti compared to the $D$. radiodurans model.
\end{abstract}

Keyword: Proteome, Post-translational modification, Irradiation, Early response, Reference 2D map, Kinetics, Hierarchical clustering

\section{Introduction}

Deinococcus deserti belongs to the Deinococcaceae, a group of extremely radiotolerant bacteria. $D$. deserti VCD115 has been isolated from upper sand layers of the Sahara desert [1]. In this environment, cells are exposed to very changing life conditions with cycles of high temperatures, high UV irradiation, desiccating conditions, low temperatures and rehydrating conditions. Probably as a consequence of adaptation to such harsh, DNA-

\footnotetext{
* Correspondence: alain.dedieu@cea.fr

'Laboratoire de Biochimie des Systèmes Perturbés, CEA Marcoule, DSV, iBEB, SBTN, LBSP, BAGNOLS-SUR-CEZE F-30207, France

Full list of author information is available at the end of the article
}

damaging conditions, $D$. deserti and other Deinococcaceae $[2,3]$ exhibit an extraordinary ability to withstand ioni zing radiation. Chromosomes with numerous radiationor desiccation-induced double-strand breaks can be repaired in a few hours in $D$. deserti [4]. To learn about the specificities of this bacterium compared with other Deinococcaceae, its entire genome sequence has been determined [4]. It consists of a $2.8-\mathrm{Mb}$ chromosome and three large plasmids called P1 (324 kb), P2 (314 kb), and P3 (396 kb). The comparative analysis showed some interesting differences between $D$. deserti and other sequenced Deinococcus species. For example, D. deserti possesses supplementary genes involved in DNA repair, such as

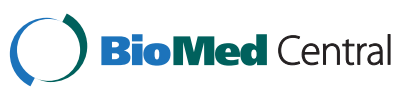


three $\operatorname{rec} A$ that code for two different RecA proteins, whereas it lacks homologs of several radiation-induced genes in Deinococcus radiodurans (e.g., $d d r P$ encoding a putative DNA ligase).

The extreme radiotolerance of Deinococcaceae was the object of intense investigations during the last years using $D$. radiodurans as model. In cells subjected to irradiation, DNA recombinase RecA was the first protein that was found strongly induced [5]. RecA is essential for radiotolerance [6] and for the fidelity of DNA repair and genome stability in D. radiodurans [7]. The molecular mechanisms underlying DNA repair were also examined by transcriptomics [8-10] leading to the description of a repertoire of genes responding to acute gamma irradiation, including genes involved in DNA replication, repair and recombination, cell wall metabolism, cellular transport and many with uncharacterized functions. Another transcriptional study has shown that 72 genes were up-regulated three fold or higher in D. radiodurans following gamma irradiation [11]. In this study, besides genes with already known assigned function linked to DNA repair ( $g y r A, \operatorname{gyr} B, u v r A, u v r B, \operatorname{ruvB}$ and $\operatorname{rec} A$ ), five novel genes with unknown or hypothetical assigned functions were highlighted: $d d r A, d d r B, d d r C, d d r D$ and pprA (ddr, DNA damage response; ppr, pleiotropic protein promoting DNA repair). Genetic analyses demonstrated a role of these five genes in radiotolerance [11], and further studies have reported that DdrA, DdrB and PprA are involved in DNA repair [12-19]. Radiotolerance of $D$. radiodurans probably results from a combination of different highly coordinated physiological pathways [20]. Besides enzymatic pathways such as DNA repair, passive contributions to radiotolerance have been described such as the nucleoid structure where DNA molecules are highly condensed, which would limit diffusion of DNA fragments [21], and the high intracellular $\mathrm{Mn}^{2+} / \mathrm{Fe}^{2+}$ ratio that limits protein oxidation [20,22-24]. Today, the survival kit components of Deinococcaceae are far to be exhaustive and some possible factors remain controversial [25].

To further analyze these mechanisms of radioresistance, proteomic approaches are promising as both mass spectrometry (MS) tools and protein separation techniques are ultimately quickly improving [26]. As gene expression and presence of the corresponding protein in the cell are not always strictly correlated, it is worth to compile multi-omics data on such subject [27]. Zhang et al. [28] identified by a classical 2D electrophoresis (2DE) gel approach 21 proteins whose cellular levels significantly changed following $\gamma$-irradiation of $D$. radiodurans. Surprisingly, among them few proteins are directly related to DNA metabolism. A comparative 2DE gel-based proteomic study, using the wild-type and a pprI knock-out strain, has shown that 31 proteins are up-regulated after exposure to low dose of $\gamma$ radiation in a PprI-dependent manner in D. radiodurans [29]. PprI, also called IrrE, is a Deinococcus-specific transcriptional factor essential for radiotolerance [30-32]. Moreover, phosphorylation of two proteins (DR_A0283 which encodes a serine protease and DR_1343, a glyceraldehyde-3-phosphate dehydrogenase) was shown to be dependent upon the presence of PprI. More recently, a 2D-proteome reference map has been reported for Deinococcus geothermalis grown in standard conditions [33], as well as a shotgun analysis of its major membrane components [34].

Comparisons of the genome sequences of various Deinococcaceae shed new light on their potential arsenal related to DNA repair and radiotolerance $[4,35,36]$. Convinced that comparison of the proteome dynamics of several species will also be fruitful, we performed a time course analysis of the proteome of $D$. deserti after exposure to $3 \mathrm{kGy} \gamma$-radiations. The proteome from cells harvested at different time lapses after irradiation were analyzed with a 2-D gel approach. A hierarchical clustering analysis pointed at accumulated proteins at the earliest stages after irradiation. Among these are several important DNA repair proteins. Interestingly, post-translational modifications of GyrA were detected. We also observed the up-regulation of novel proteins such as the conserved Deide_20140 acetyltransferase, Deide_19260 response regulator, Deide_21840 PilT protein, as well as specific $D$. deserti proteins such as the Deide_02842 restriction enzyme. The physiological significance of these novel results is discussed.

\section{Results}

Time course analysis of $D$. deserti cells after drastic irradiation

We established a reference proteome map for $D$. deserti cells harvested at the exponential phase (Additional file 1: Figure S1 \& Additional file 2: Table S1). We observed that several stress response and DNA repair proteins are already found in standard condition, for example two desiccation tolerance-associated proteins (Deide_07540, Deide_08510) and $\operatorname{Rec}_{C}$ (Deide_19450). We investigated the time-dependent changes in the proteome of $D$. deserti after drastic irradiation conditions. Two independent cultures of $D$. deserti VCD115 cells were grown overnight to reach an optical density of 0.4 . Each culture was exposed to $3 \mathrm{kGy}$ of gamma rays. After irradiation, each culture was incubated without change of growth medium to avoid any additional stress. Sampling took place immediately before irradiation and $0,2,4,6,8,22$ and 30 hours postirradiation. We performed 2DE-gels from our two biological replicates with a specific effort in terms of technical replicates for time-points before irradiation and right after (0, 2 and 4 hours) in order to detect tiny changes in 
protein accumulation. In parallel to the 2DE-gel analysis, cell growth as well as DNA damage and repair was followed at the different time points. Figure 1 shows that while DNA is broken in small pieces by irradiation, DNA repair is slow in our experimental set-up with completion visible at 22 hours. Therefore, the early stages of DNA repair can be analyzed following the 2, 4, 6, and 8-hour time-points. No growth was observed for the first $22 \mathrm{~h}$ (Additional file 3: Figure S2). The cells have started to grow only $30 \mathrm{~h}$ post-irradiation. This is in agreement with the PFGE data (Figure 1) that show an increased amount of DNA due to replication at $30 \mathrm{~h}$.

\section{Proteins involved in response to drastic irradiation conditions}

We determined the concentration of total proteins for each sample and deposited the same amount of proteins for each gel. We matched with the ImageMaster software the gels belonging to the same class, i.e. same time point. When comparing the different classes a significant trend was observed in terms of number of spots. The number of spots reported here is a mean value of the replicates. While before irradiation, roughly $488( \pm 29)$ spots were delineated, only $467( \pm 65)$ were detected at 0h, $458( \pm 112)$ at $2 \mathrm{~h}, 425(( \pm 98)$ at $4 \mathrm{~h}$ and $411( \pm 3)$ at $6 \mathrm{~h}$ and $410( \pm 90)$ at 8 hours. An increase to $526( \pm 14)$ and $546( \pm 100)$ spots was recorded for 22 and 30 hours, respectively. The minimum for both biological duplicates was reached 4-6 hours after irradiation. As it will be discussed below, the presence in large quantities of at least

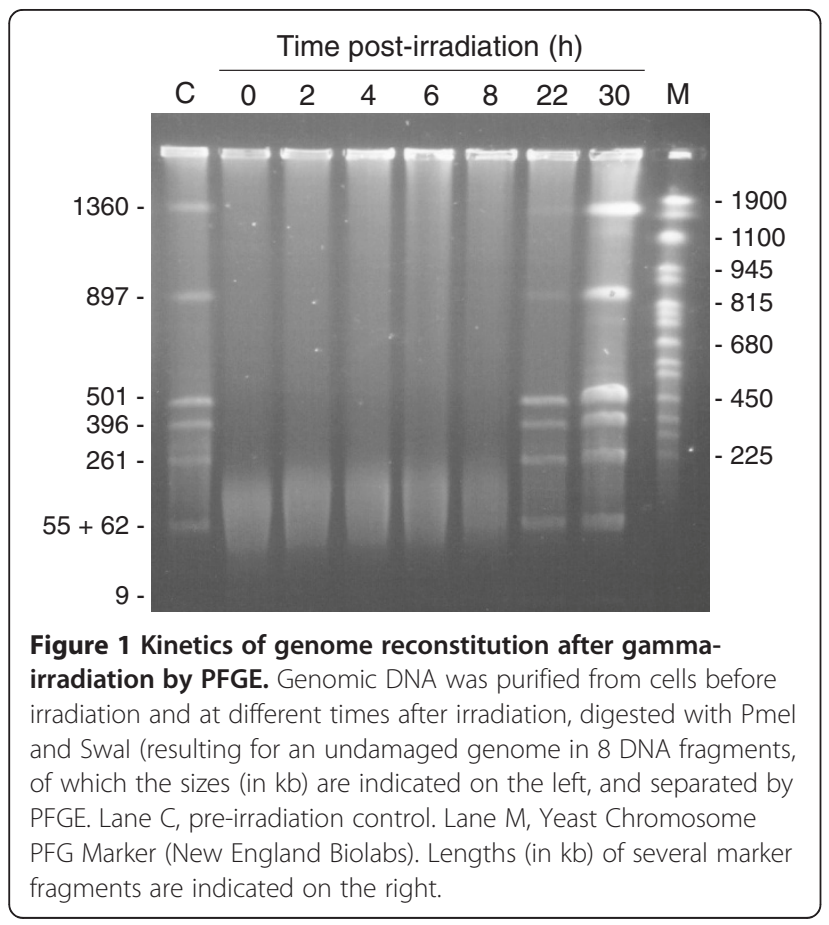

two proteases up-regulated in the first stages after irradiation could explain this phenomenon.

After comparing gel images with the statistical tools implemented in the ImageMaster software, we detected five spots that were significantly increased in intensity after irradiation, with fold changes above $1.5(\mathrm{p}<0.05)$. Figure 2 shows image captures of three of these spots and fold changes associated along the time courses. They are clearly more intense at 2, 4 and 6 hours and remain high at 8 and $22 \mathrm{~h}$, which is in agreement with the kinetics of the genome recovery shown in Figure 1. We analyzed by MS the polypeptide content of each of these spots throughout the whole time course. The three series of spots shown in Figure 2 correspond to: Deide_1p01260/Deide_3p00210 (RecA $\left.{ }_{P}\right)$ and Deide_19450 $\left(\right.$ RecA $\left._{C}\right)$ in spot sp_411, Deide_02990 (DdrB; spot sp_683), and Deide_15490 (GyrB, subunit B of DNA gyrase; spot sp_101). The two others are Deide_00120 (SSB; spot sp_494) and Deide_2p01380 (PprA; spot sp_523) (data not shown). The two recA genes on plasmids P1 and P3 code for exactly the same protein named $\operatorname{Rec}_{\mathrm{P}}$ which shares $81 \%$ sequence identity with the chromosome-encoded RecA $A_{C}$. They can be easily distinguished from each other with several proteotypic peptides (Additional file 4: Figure S3). Under the spot sp_411, Rec $A_{P}$ is detected sooner along the time course and always in larger quantity compared with $\operatorname{Rec} A_{C}$. These six proteins are all involved in DNA protection or repair as implied by several studies performed with the $D$. radiodurans model $[8,11,37]$, or, for the different RecA proteins, with the $D$. deserti model [38]. Deide_02990 (DdrB) is clearly accumulating from 2 hours after irradiation (fold change $\sim 3$ ). Its presence is maximal at 6 hours (fold change $\sim 11$ ) in the time course whatever the biological replicate. The accumulation of Deide_00120 (SSB) is also detected early, as soon as 2 hours after irradiation. In this case, the fold change remains moderate $(\sim 2.5)$ till 8 hours. Abundance of $\operatorname{RecA}_{\mathrm{P}}, \operatorname{Rec}_{C}, \mathrm{GyrB}, \mathrm{PprA}$ is significantly increased only after 4 hours in our experimental set-up. We did not detect with confidence down-regulated proteins with such fold changes.

\section{Hierarchical clustering methodologies revealed novel key proteins in the early and delayed responses}

Clustering and heat map visualization was performed to identify groups of co-regulated proteins whose expression change over time. Figure 3 shows three clusters, namely red, orange and green clusters, corresponding to proteins accumulating at early stages: $2 \mathrm{~h}$ (high abundance increase), $2 \mathrm{~h}$ (less pronounced abundance increase), and $4 \mathrm{~h}$ after irradiation, respectively. We identified the polypeptides present in these spots and confirmed their presence along the whole time course if 


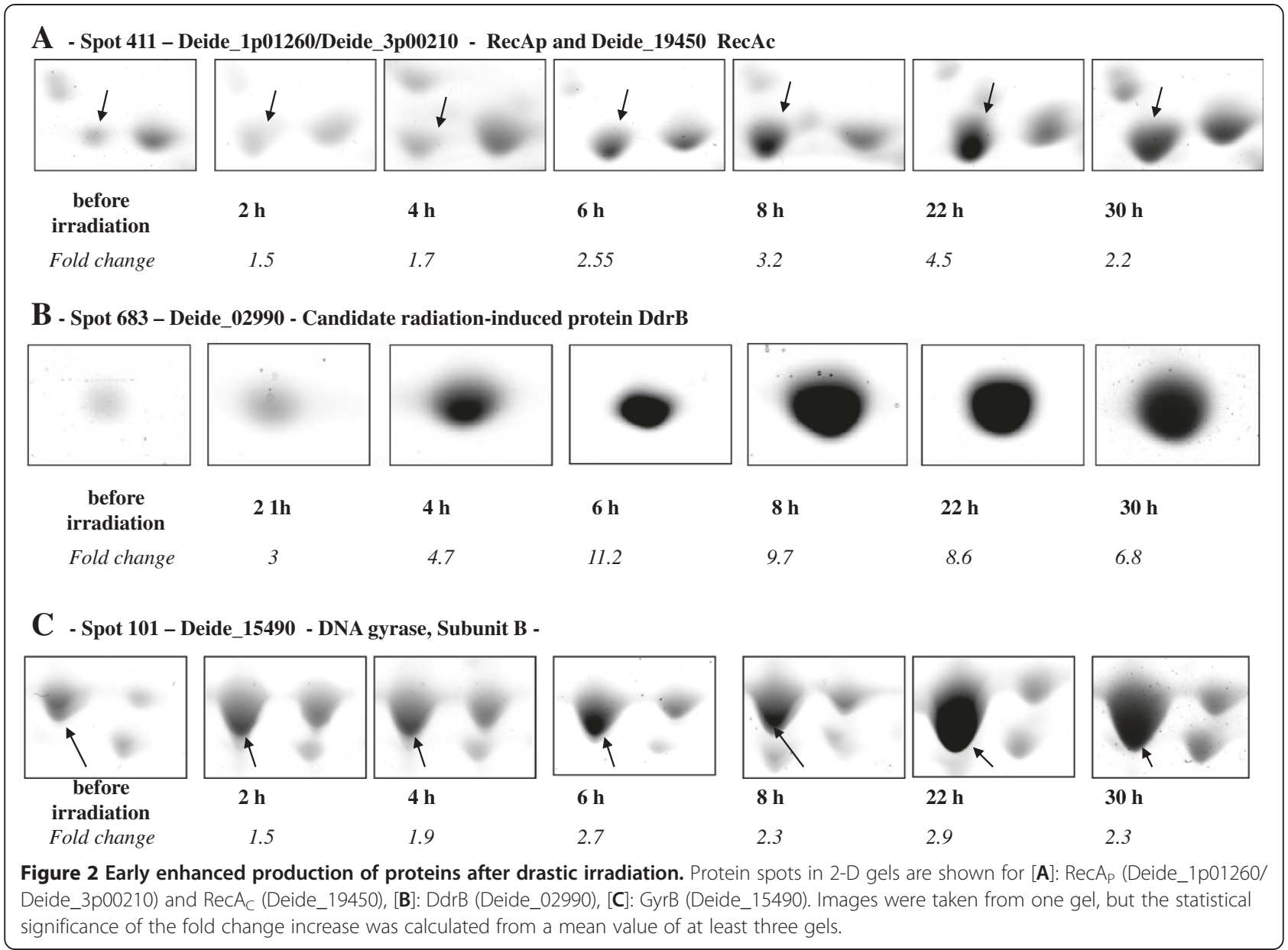

relevant. Table 1 presents the main characteristics of these proteins and the fold changes along the time course after irradiation. The "red" cluster comprises seven spots. Among these, five spots containing six proteins were already detected earlier in our direct gel $t$-test comparison. In the two additional spots, four new proteins were revealed: Deide_12520 (DNA gyrase subunit A) on the first hand, Deide_19260 (response regulator of the SarP family), Deide_20140 (GCN5-related N-acetyltransferase) and Deide_21840 (predicted twitching mobility protein) on the other.

The "orange" cluster comprises five spots slightly more intense from 2 hours after irradiation, but not as much as the former cluster. In these five spots we could identify six up-regulated proteins (Table 1): Deide_12520 (DNA gyrase subunit A) which appeared previously in the "red" cluster in a clearly distinguishable spot, Deide_19450 (chromosome-encoded RecA $A_{C}$ ), Deide_02842 (a protein related to Type II site-specific deoxyribonuclease), Deide_14090 (a kinase involved in LAO/AO transport system), Deide_13740 (signal recognition particle-docking protein FtsY/cell division protein FtsY), and Deide_01160 (homologue of the $D$. radiodurans radiation-induced protein DdrD). In spot sp_400 (orange cluster), $\operatorname{Rec}_{\mathrm{C}}$ is detected by many proteotypic peptides.

The "green" cluster comprises nine spots whose intensities slightly increase from 4 hours. From these spots we could identify 9 different up-regulated proteins (Table 1). Among these, several proteins are related to central metabolism (Deide_16440, Deide_1p00780, Deide_15960) and protein turn-over (the Deide_19590 La protease and Deide_02310 dipeptidyl aminopeptidase). Remarkably, we found within this cluster three novel spots corresponding to the gyrase subunits, Deide_12520 and Deide_15490. We also found up-regulation of DNA helicase UvrD (Deide_12100). UvrD plays a major role in Double-Strand Break repair through Extended Synthesis-Dependent Strand Annealing [39]. Last but not least, we found the EngA GTPase (Deide_23290) that was shown essential for cell viability in $E$. coli and required for ribosome assembly and stability [40].

\section{Evidences for post-translational modifications of GyrA $\mathrm{N}$-terminus}

We detected several distinguishable spots (spots sp_58, sp_59, sp_60, and sp_61) belonging to the three different 


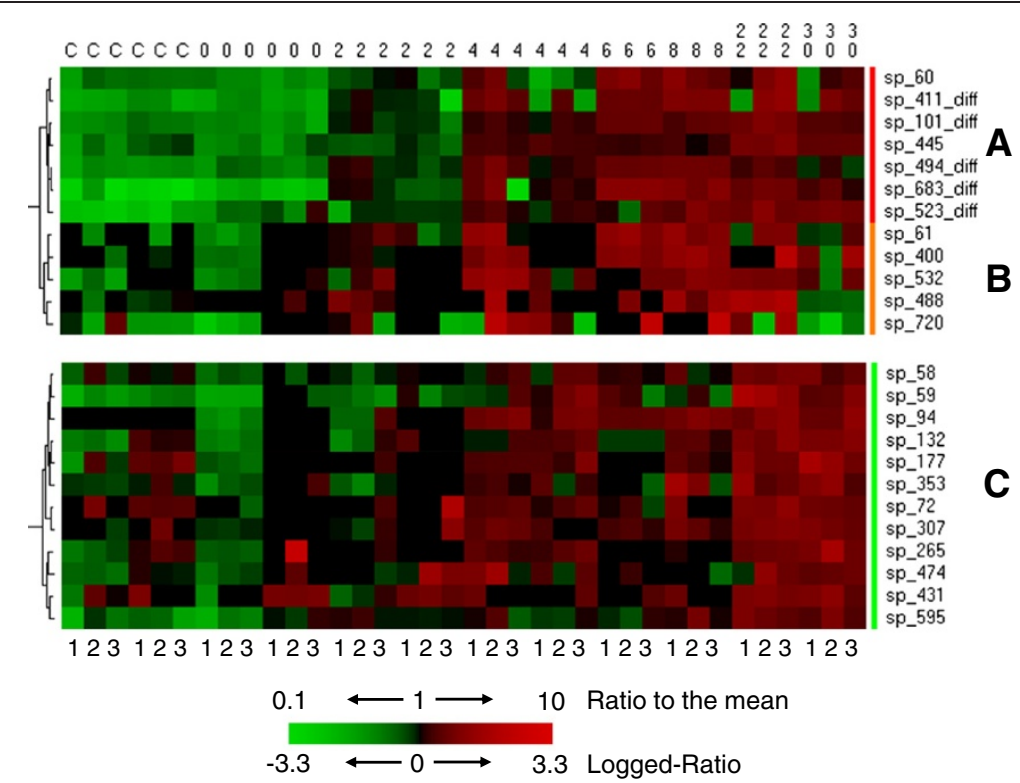

Figure 3 Hierarchical clustering to identify early accumulating proteins. Three clusters were selected from hierarchical clustering results. $\mathbf{A}$ (red cluster) and $\mathbf{B}$ (orange cluster) look very similar with up-regulated proteins at an early stage (2 hours after irradiation) but are statistically different. The red cluster contains 5 spots already detected by the statistic method implemented in the ImageMaster software (indicated with diff). The third one $\mathbf{C}$ (green cluster) gathers proteins up-regulated from 4 hours and beyond. The dendogram on the left indicates the order of the protein grouping. The intensities (protein accumulation) range from bright green (underproduced in comparison with the mean value) to bright red (overproduced in comparison with the mean value) according to the color scale at the bottom of the figure. The three successive columns for each biological sample correspond to the corresponding 3 technical replicates recorded and they are numbered in the bottom of the figure. Red and orange clusters are statistically different partly because of (i) missing values and (ii) inability of the statistical method available in the software program to analyze gel images (here, ImageMaster 2D) to detect these spots in some gels.

HCA clusters for the subunit A of gyrase (Deide_12520). Whether a post-translational modification such as SerThr-Tyr phosphorylation, Lys or N-terminus acetylation, methylation, or maturation by proteases could explain this behaviour was investigated. In these spots, we found that the GyrA polypeptide is modified with the removal of its first residue (methionine) as can be expected because the second residue in the unmatured polypeptidic chain has a small lateral chain. Figure 4 shows the MS/ MS spectrum of the N-terminal most peptide [TGIHPVDITSEVK] resulting from this specific modification. Moreover, for the spectrum of this peptide obtained with a LTQ-Orbitrap-XL mass spectrometer, the $b_{3}$ ion with a $\mathrm{m} / \mathrm{z}$ value of 314.17 indicated that an acetylation occurs on the TGI N-terminal tripeptide while the parent mass is unambiguously determined with a precision below $1 \mathrm{ppm}$. We noted that the first threonine residue can be partially acetylated as another MS/MS spectrum corresponded to the unacetylated [TGIHPVDITSEVK] form, with a $m / z$ of the parent at 632.33 and a charge of $2^{+}$. A pI shift for acidic or neutral proteins due to acetylation has been observed $[41,42]$. While a mixture of acetylated peptide and non-modified peptide is seen in spots sp_59, sp_60, and sp_61, only the acetylated form is detected in spot sp_58. While this post-translational modification could explain the shift for spot sp_58, other differences between the three other spots should come from additional post-translational modifications. Interestingly, the up-regulation of Deide_20140 (a putative N-acetyl transferase) as presented in Table 1 could explain differences in acetylation pattern.

\section{Discussion}

Following the proteome dynamics of $D$. deserti after irradiation by a $2 \mathrm{DE}$-gel approach highlighted the upregulation of 21 proteins. Among these, ten proteins either have no homolog in D. radiodurans or were not found to be radiation-induced at the protein or RNA level in this organism (see Additional file 5: Table S2 and below), whereas eight others are known to be important players of the irradiation response in $D$. radiodurans: DdrB, SSB, PprA, RecA, GyrA/B, UvrD and DdrD. Concerning RecA, a notable difference is that two functionally different RecA proteins are up-regulated in $D$. deserti. The other sequenced Deinococcus species possess only one recA gene. Both $\operatorname{Rec}_{C}$ and $\operatorname{Rec}_{\mathrm{P}}$ contribute to radiotolerance, but only $\operatorname{Rec}_{C}$ is able to induce expression of DNA translesion polymerases in $D$. deserti [38]. The proteomic results obtained by Zhang et al. [28] from the 2D-gel based analysis of $D$. radiodurans after irradiation did not reveal the presence of GyrB and RecA while transcriptomics revealed the up-regulation of 


\begin{tabular}{|c|c|c|c|c|c|c|c|c|c|c|c|c|c|c|c|c|c|c|c|c|}
\hline \multirow[t]{3}{*}{ Spot } & \multirow{3}{*}{$\begin{array}{l}\text { Protein } \\
\text { identification }\end{array}$} & \multirow[t]{3}{*}{ Protein description } & \multicolumn{18}{|c|}{ Time (h) post irradiation } \\
\hline & & & \multicolumn{3}{|c|}{2} & \multicolumn{3}{|c|}{4} & \multicolumn{3}{|c|}{6} & \multicolumn{3}{|c|}{8} & \multicolumn{3}{|c|}{22} & \multicolumn{3}{|c|}{30} \\
\hline & & & $\begin{array}{l}\mathrm{FC} \\
(2 / \mathrm{ct})\end{array}$ & $\begin{array}{l}\% \\
\text { VOL }\end{array}$ & $\begin{array}{l}\mathrm{t}- \\
\text { test }\end{array}$ & $\begin{array}{l}\mathrm{FC} \\
(4 / \mathrm{ct})\end{array}$ & $\begin{array}{l}\% \\
\text { VOL }\end{array}$ & $\begin{array}{l}\text { t- } \\
\text { test }\end{array}$ & $\begin{array}{l}\mathrm{FC} \\
(6 / c t)\end{array}$ & $\begin{array}{l}\% \\
\text { VOL }\end{array}$ & $\begin{array}{l}\text { t- } \\
\text { test }\end{array}$ & $\begin{array}{l}\mathrm{FC} \\
(8 / \mathrm{ct})\end{array}$ & $\begin{array}{l}\% \\
\text { VOL }\end{array}$ & $\begin{array}{l}\mathrm{t}- \\
\text { test }\end{array}$ & $\begin{array}{l}\mathrm{FC} \\
(22 / \mathrm{ct})\end{array}$ & $\begin{array}{l}\% \\
\text { VOL }\end{array}$ & $\begin{array}{l}\mathrm{t}- \\
\text { test }\end{array}$ & $\begin{array}{l}\text { FC } \\
(30 / c t)\end{array}$ & $\begin{array}{l}\% \\
\text { VOL }\end{array}$ & $\begin{array}{l}\mathrm{t}- \\
\text { test }\end{array}$ \\
\hline sp_60 & Deide_12520 & DNA gyrase, subunit A & 1,64 & 0,14 & $<0,01$ & 1,84 & 0,16 & 0,02 & 3,89 & 0,34 & $<0,01$ & 3,59 & 0,31 & $<0,01$ & 3,68 & 0,32 & $<0,01$ & 2,00 & 0,18 & $<0,01$ \\
\hline sp_101_diff & Deide_15490 & DNA gyrase, subunit B & 1,82 & 0,39 & $<0,01$ & 2,44 & 0,53 & $<0,01$ & 3,36 & 0,72 & $<0,01$ & 3,07 & 0,66 & $<0,01$ & 3,93 & 0,85 & $<0,01$ & 2,85 & 0,62 & $<0,01$ \\
\hline sp_411_diff & $\begin{array}{l}\text { Deide_1p01260/ } \\
\text { Deide_3p00210 }\end{array}$ & $\operatorname{Rec} A_{p}$ & 2,28 & 0,16 & $<0,01$ & 3,31 & 0,23 & $<0,01$ & 4,51 & 0,31 & $<0,01$ & 5,62 & 0,39 & $<0,01$ & 4,91 & 0,34 & $<0,01$ & 3,74 & 0,26 & $<0,01$ \\
\hline sp_445 & Deide_20140 & $\begin{array}{l}\text { GCN5-related N- } \\
\text { acetyltransferase }\end{array}$ & 1,29 & 0,08 & 0,09 & 2,21 & 0,14 & $<0,01$ & 2,06 & 0,13 & $<0,01$ & 2,03 & 0,13 & $<0,01$ & 3,35 & 0,21 & $<0,01$ & 2,67 & 0,17 & $<0,01$ \\
\hline sp_445 & Deide_19260 & response regulator, SarP & 1,29 & 0,08 & 0,09 & 2,21 & 0,14 & $<0,01$ & 2,06 & 0,13 & $<0,01$ & 2,03 & 0,13 & $<0,01$ & 3,35 & 0,21 & $<0,01$ & 2,67 & 0,17 & $<0,01$ \\
\hline sp_445 & Deide_21840 & twitching mobility protein & 1,29 & 0,08 & 0,09 & 2,21 & 0,14 & $<0,01$ & 2,06 & 0,13 & $<0,01$ & 2,03 & 0,13 & $<0,01$ & 3,35 & 0,21 & $<0,01$ & 2,67 & 0,17 & $<0,01$ \\
\hline sp_494_diff & Deide_00120 & $\begin{array}{l}\text { single-stranded DNA-binding } \\
\text { protein }\end{array}$ & 2,05 & 0,37 & $<0,01$ & 2,85 & 0,52 & $<0,01$ & 3,40 & 0,62 & $<0,01$ & 3,63 & 0,66 & $<0,01$ & 2,84 & 0,52 & $<0,01$ & 2,07 & 0,38 & $<0,01$ \\
\hline sp_523_diff & Deide_2p01380 & DNA repair protein PprA & 1,81 & 0,14 & 0,05 & 2,66 & 0,21 & $<0,01$ & 2,50 & 0,20 & 0,04 & 4,05 & 0,32 & $<0,01$ & 4,32 & 0,34 & $<0,01$ & 4,13 & 0,33 & $<0,01$ \\
\hline sp_683_diff & Deide_02990 & $\begin{array}{l}\text { DNA damage response protein } \\
\text { DdrB }\end{array}$ & 4,50 & 0,57 & $<0,01$ & 5,99 & 0,76 & $<0,01$ & 11,98 & 1,52 & $<0,01$ & 10,51 & 1,33 & $<0,01$ & 8,86 & 1,12 & $<0,01$ & 6,83 & 0,87 & $<0,01$ \\
\hline sp_61 & Deide_12520 & DNA gyrase, subunit A & 2,51 & 0,07 & $<0,01$ & 4,77 & 0,13 & 0,01 & 5,49 & 0,15 & $<0,01$ & 5,10 & 0,14 & $<0,01$ & 3,66 & 0,10 & 0,01 & 2,42 & 0,07 & 0,01 \\
\hline sp_400 & Deide_19450 & $\operatorname{Rec}_{C}$ & 1,55 & 0,28 & 0,06 & 3,05 & 0,55 & $<0,01$ & 3,12 & 0,57 & $<0,01$ & 3,69 & 0,67 & $<0,01$ & 5,92 & 1,07 & $<0,01$ & 2,64 & 0,48 & ns \\
\hline sp_488 & Deide_13740 & $\begin{array}{l}\text { signal recognition particle- } \\
\text { docking protein FtsY }\end{array}$ & 1,69 & 0,03 & 0,12 & 2,66 & 0,05 & 0,06 & 2,45 & 0,04 & 0,01 & 2,58 & 0,04 & 0,02 & 3,89 & 0,07 & $<0,01$ & 0,75 & 0,01 & ns \\
\hline sp_532 & Deide_02842 & $\begin{array}{l}\text { Type II site-specific } \\
\text { deoxyribonuclease }\end{array}$ & 2,13 & 0,06 & 0,06 & 3,22 & 0,09 & 0,01 & 3,10 & 0,09 & $<0,01$ & 3,54 & 0,10 & $<0,01$ & 3,26 & 0,09 & $<0,01$ & 2,04 & 0,06 & 0,06 \\
\hline sp_532 & Deide_14090 & $\begin{array}{l}\mathrm{LAO} / \mathrm{AO} \text { transport system } \\
\text { kinase }\end{array}$ & 2,13 & 0,06 & 0,06 & 3,22 & 0,09 & 0,01 & 3,10 & 0,09 & $<0,01$ & 3,54 & 0,10 & $<0,01$ & 3,26 & 0,09 & $<0,01$ & 2,04 & 0,06 & 0,06 \\
\hline sp_720 & Deide_01160 & $\begin{array}{l}\text { DNA damage response protein } \\
\text { DdrD }\end{array}$ & 1,48 & 0,07 & ns & 5,00 & 0,23 & 0,03 & 10,23 & 0,46 & $<0,01$ & 10,24 & 0,46 & $<0,01$ & 3,29 & 0,15 & 0,19 & 0,67 & 0,03 & ns \\
\hline sp_58 & Deide_19590 & ATP-dependent protease La & 1,06 & 0,07 & ns & 1,43 & 0,09 & 0,01 & 1,28 & 0,09 & 0,14 & 1,34 & 0,09 & 0,08 & 2,06 & 0,14 & $<0,01$ & 1,85 & 0,12 & $<0,01$ \\
\hline sp_58 & Deide_12520 & DNA gyrase, subunit A & 1,06 & 0,07 & ns & 1,43 & 0,09 & 0,01 & 1,28 & 0,09 & 0,14 & 1,34 & 0,09 & 0,08 & 2,06 & 0,14 & $<0,01$ & 1,85 & 0,12 & $<0,01$ \\
\hline sp_59 & Deide_12520 & DNA gyrase, subunit A & 1,45 & 0,06 & ns & 2,96 & 0,12 & $<0,01$ & 2,28 & 0,09 & 0,01 & 4,60 & 0,18 & 0,04 & 6,60 & 0,26 & $<0,01$ & 3,67 & 0,14 & $<0,01$ \\
\hline sp_72 & Deide_12100 & DNA helicase II (UvrD) & 1,16 & 0,03 & ns & 1,20 & 0,03 & 0,25 & 0,77 & 0,02 & ns & 7,62 & 0,18 & 0,10 & 1,56 & 0,04 & 0,04 & 1,23 & 0,03 & ns \\
\hline sp_94 & Deide_15490 & DNA gyrase, subunit B & 1,95 & 0,04 & ns & 3,80 & 0,07 & $<0,01$ & 3,28 & 0,06 & 0,01 & 4,11 & 0,08 & $<0,01$ & 4,45 & 0,09 & 0,01 & 4,07 & 0,08 & 0,03 \\
\hline sp_132 & Deide_02310 & dipeptidyl aminopeptidase & 1,19 & 0,04 & ns & 1,63 & 0,06 & 0,01 & 1,12 & 0,04 & ns & 1,73 & 0,06 & 0,03 & 2,62 & 0,09 & $<0,01$ & 2,61 & 0,09 & $<0,01$ \\
\hline sp_307 & Deide_23290 & GTP-binding protein & 1,30 & 0,07 & ns & 1,34 & 0,07 & ns & 1,12 & 0,06 & ns & 1,64 & 0,09 & 0,10 & 1,83 & 0,10 & 0,05 & 1,64 & 0,09 & 0,12 \\
\hline
\end{tabular}


Table 1 Radiation-induced proteins identified by hierarchical clustering analysis (Continued)

\begin{tabular}{|c|c|c|c|c|c|c|c|c|c|c|c|c|c|c|c|c|c|c|c|c|}
\hline sp_353 & Deide_16440 & $\begin{array}{l}\text { biotin synthase/thiamine } \\
\text { biosynthesis enzyme }\end{array}$ & 0,79 & 0,02 & ns & 1,29 & 0,04 & 0,07 & 5,14 & 0,15 & 0,03 & 2,21 & 0,07 & 0,06 & 2,12 & 0,06 & $<0,01$ & 2,17 & 0,06 & $<0,01$ \\
\hline sp_474 & Deide_1p00780 & $\begin{array}{l}\text { flavin dependant } \\
\text { oxidoreductase }\end{array}$ & 1,78 & 0,04 & 0,10 & 1,70 & 0,04 & 0,06 & 1,83 & 0,04 & 0,02 & 1,63 & 0,04 & 0,07 & 1,88 & 0,04 & 0,05 & 1,78 & 0,04 & 0,01 \\
\hline sp_595 & Deide_15960 & NADH dehydrogenase & 1,72 & 0,06 & 0,02 & 1,60 & 0,06 & 0,04 & 1,55 & 0,05 & ns & 2,18 & 0,08 & 0,01 & 2,82 & 0,10 & $<0,01$ & 2,58 & 0,09 & $<0$ \\
\hline
\end{tabular}

$\mathrm{FC}$, fold change; \%VOL, averaged spot intensity calculated as the relative volume; ns, not significant; ct, control (average of intensity at time 0 and before irradiation).

When several proteins were identified in the same gel spot, the number of peptides, the percentage of sequence coverage, and the emPAl score of each protein were analysed. If the variation of these parameters When several proteins were identified in the same gel spot, the number of peptides, the percentage of sequence coverage,
were identical between the identified abundant proteins, the global fold change of the spot was assigned to these proteins. 


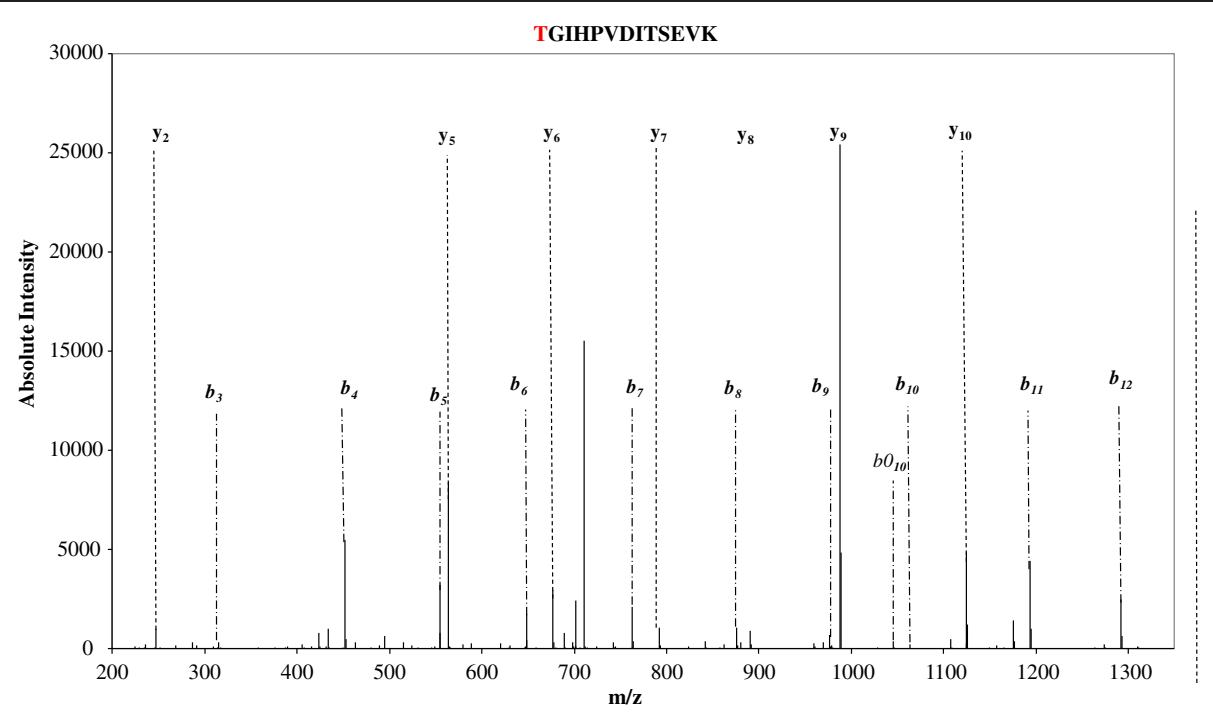

Figure $4 \mathrm{MS} / \mathrm{MS}$ evidences for post-translational modifications of the most N-terminal peptide of GyrA. The figure shows the MS/MS spectrum of a $2^{+}$charged peptide ion at $719.38 \mathrm{~m} / \mathrm{z}$ corresponding to the sequence [TGIHPVDITSEVK] with an acetylation at its $\mathrm{N}$-terminus. As shown in the spectrum, all the main peaks correspond to the complementary $y$ and $b$ ion series of this modified GyrA most- $N$ terminal peptide.

their genes [11] (Additional file 5: Table S2). Lu et al. [29] did see RecA induction, but apparently not GyrA, GyrB, DdrB, and DdrD accumulation. Here, we found a good correlation with the transcriptomics data obtained with $D$. radiodurans because GyrA, GyrB, RecA, DdrB and DdrD polypeptides are found accumulating in large quantities from 2 hours after irradiation. While this work was in progress, a new proteomic study with $D$. radiodurans was published, also showing up-regulation of GyrA, GyrB and DdrB, but not of DdrD (Additional file 5: Table S2). Using a 2DE-gel approach, Basu \& Apte [37] identified ten and two different forms of induced SSB and DdrB, respectively, with each form in a different spot. These different forms are likely resulting from proteolytic processing of the Cterminal end of these proteins [37]. In our study with $D$. deserti, we identified up-regulated SSB and DdrB in only one spot each. Interestingly, we found different spots for both GyrA and GyrB (see below). The use of different bacterial species and experimental conditions are likely explanations for the differences between our results and those previously published on $D$. radiodurans [37].

Remarkably, we found the presence of several spots assigned to the same protein: four (spots sp_58, sp_59, sp_60, sp_61) and two (spots sp_101, sp_94) spots correspond to the GyrA and GyrB subunits, respectively. The different forms of Deide_12520 (GyrA) detected in the three HCA clusters are produced in higher amount after irradiation. The GyrA spots (spots sp_58, sp_59, sp_60, and sp_61) are only separated by small $\mathrm{p} I$ shifts. As reported previously by Zhu et al. [42], shifts in $\mathrm{p} I$ often correlate to protein modifications. These modifications include truncations or deletions, but also post- translational modifications of amino acid lateral chains such as phosphorylation or acetylation. They can also be due in a limited number of cases to alternative translation starts as revealed in an extensive survey of $\mathrm{N}$ termini of proteins from $D$. deserti [43], or N-terminal trimming by exo-peptidases. At the $\mathrm{N}$-terminus and side chains of amino groups, post-translational modifications will lead generally to small $(<0.2)$ isoelectric point shift. Here, we observed a sequence coverage of $\sim 30 \%$ with the GyrA peptides in the four spots. We detected the [2TGIHPVDITSEV-13] and the [790-VINIAERDSVISAFPIRR-807] peptides that are very close from the expected $\mathrm{N}$-terminal and C-terminal extremities of the 811 amino acid-long GyrA. For this reason, a small truncation of the protein is unlikely, except maturation of the $\mathrm{N}$ terminus (removal of the initial methionine) as evidenced by the most-N-terminal peptide. Regarding posttranslational modification of GyrA, we could not detect any phosphorylation for serine, threonine or tyrosine residues, nor acetylation of the lysine side chains within the detected peptides. However, we found that GyrA $\mathrm{N}$-terminus is acetylated. While a mixture of acetylated peptide and non-modified peptide is seen in spots sp_59, sp_60, and sp_61, only the acetylated form is detected in spot sp_58. For eukaryotic proteins acetylation is one of the most common covalent modifications with phosphorylation [44] while it is not frequent for prokaryotic proteins $[45,46]$ even if prokaryotic proteins are also extensively post-translationally modified [47]. Amino-terminal acetylation occurs co-translationally with eukaryotic proteins [45] and post-translationally in the case of prokaryotic proteins [48]. Acetylation may affect protein functions as their 
stability and DNA binding activity may be modified; the hyperacetylation of histones being the most illustrative example in this respect as it influences drastically transcription [49]. Hwang et al. [50] noted that N-terminal acetylation of proteins could act as a degradation signal in yeast. Interestingly, we found the Deide_20140 GCN5related acetyltransferase being up-regulated in the earliest time-points after irradiation. Whether this enzyme is responsible for the acetylation observed on GyrA is an interesting hypothesis that deserves further investigation. However, at least under our experimental conditions, a potential Deide_20140-specific function is not essential for radiation resistance, since a Deide_20140 deletion mutant appeared to be as radiotolerant as the wild-type strain (data not shown). The $D$. deserti genome encodes various putative $\mathrm{N}$-acetyltransferases, and some of these might have redundant activities.

We observed two up-regulated proteases: Deide_19590 (protease La, also called Lon protease) and Deide_02310 (related to dipeptidyl-aminopeptidase/acylaminoacyl-peptidase). Of these, Deide_02310 is not conserved in other sequenced Deinococcus species. The presence of these proteases in significant amounts is delayed compared to most DNA-repair related proteins. Their up-regulation, together with the presence of several other proteases (Additional file 2: Table S1) [4], could explain the significant trend observed in terms of number of spots detected in our 2DE-gels. A very active protein turn-over occurs because of protein damages and intense metabolic changes. Protein degradation after exposure to radiation was also reported for $D$. radiodurans [51], which also encodes a high number of proteases. Other data indicated that Lon proteases play a key role in degradation of damaged proteins in D. radiodurans [52]. Proteolysis may also control the levels of radiation-induced proteins, as shown for E. coli where numerous SOS response proteins, including RecA and UvrA, are substrates for ClpPX, Lon and other proteases $[53,54]$. Accumulated levels of some DNA repair proteins can be deleterious, and their activity must be restricted to regions of DNA damage. Translesion DNA polymerases are other examples of induced proteins that are rapidly degraded in vivo [54]. D. deserti encodes functional translesion DNA polymerases that are induced upon DNA damage [38], and their activity should be strictly controlled to prevent elevated levels of mutagenesis. Remarkably, the regulation of the dipeptidylaminopeptidase/acylaminoacyl-peptidase (Deide_02310) could explain the heterogeneity observed for the GyrA/B subunits.

Besides the already known proteins related to DNArepair or metabolic changes described above, we detected the presence of several novel proteins that probably fulfill key roles in the radiation responses in $D$. deserti. Deide_20140 presents some far-related similarities with
MshD (E value: 3.01e-09), the acetyl-transferase that catalyzes the final step of mycothiol biosynthesis in various members of the Actinomycetes. Mycothiol replaces glutathione in these species. Glutathione is a well-known antioxidant that helps protecting cells from reactive oxygen species such as free radicals and peroxides. Together with other antioxidants, such as $\mathrm{Mn}^{2+}$ complexes [5,22], the Deide_20140 acetyl-transferase in $D$. deserti could contribute to tolerance to oxidative stress, which is generated by ionizing radiation-induced water radiolysis [55]. Oxidative stress may also occur during dehydratation as described by Fredrickson and co-workers [56]. Interestingly, we observed the up-regulation at the earliest stage after irradiation of the Deide_19260 protein (COG3947) that shows strong similarities with response regulators from two-component systems. COG3947 members usually comprise two structural domains: i) at their N-terminus, a CheY-like receiver with a phosphoacceptor site (Asp52 in Deide_19260) that is phosphorylated by histidine kinase homologs and ii) a DNAbinding transcriptional activator of the SARP family at their C-terminus. We tried to check the phosphorylation status of the CheY domain, but a peptide covering residue 52 was not detected in our experiments. Such aspartatephosphorylation should be stable enough to be detected in our experimental conditions as previously found $[57,58]$.

It is worth to note that this putative two-component regulator is highly conserved in all radiotolerant Deinococcus species (70-84\% identity) and in the thermophilic and radiotolerant Truepera radiovictrix (41\% identity). However, the genetic context for Deide_19260 and its homologs is not conserved. None of the genes flanking Deide_19260 or its homologs encodes a histidine kinase in these species. The putative cognate histidine kinase for Deide_19260 is unknown. The Deide_19260 protein could be an important regulator for stress and/ or DNA-damage response in $D$. deserti, besides the previously identified IrrE transcriptional activator. It will be of interest to study the targets of the SARP regulator. However, in contrast to the radiation-sensitive $\operatorname{irrE}$ mutant [32], deletion of Deide_19260 did not result in loss of radiation tolerance (data not shown). This could mean that Deide_19260 is not involved in radiation tolerance or that its function is redundant with another response regulator. The Deide_21840 up-regulated protein is related to PilT (COG2805), a nucleotide binding protein responsible for the retraction of type IV pili, likely by pili disassembly. This retraction provides the force required for travel of bacteria in low water environments. This protein is also required for DNA uptake in several bacteria [59]. Three proposed roles for DNA uptake are genetic transformation, DNA repair, and to provide a source of nutrient [60]. PilT may thus be an important element for survival at the population level of $D$. deserti upon adverse conditions. Another up-regulated protein, Deide_02842, 
presents far-related similarities with BglI restriction enzyme of Bacillus atrophaeus, previously known as Bacillus globigii [61,62]. We can predict that, like BglI, Deide_02842 is also a type-II site-specific ribonuclease, i.e. it cleaves specifically within or close to the recognition sequence in DNA. The Deide_02841 gene predicted to encode a DNA methylase is adjacent to Deide_02842. DNA methylation by this enzyme would protect $D$. deserti's own DNA from cleavage by Deide_02842. Homologs of both genes are absent from other sequenced Deinococcus species. D. deserti may have acquired these genes by horizontal gene transfer, as suggested by their low GC percentage (46 and 50\% versus an average of $63 \%$ for the total genome) and the nearby located transposase and integrase genes. Such restriction enzyme and methylase duo is known to be involved in the protection of bacterial cells by limiting incorporation of incoming foreign DNA, such as from bacteriophages, into the host genome. The Deide_13740 up-regulated protein (FtsY signal recognition particle GTPase) constitutes a universally conserved protein targeting pathway that ensures the co-translational delivery of substrates to the membrane-bound Sec translocon [63]. Logically, the delivery of proteins synthesized in the cytosol to their correct cellular compartment is of utmost importance for the cell following gamma-irradiation. Deide_14090 shows strong sequence similarities with the ArgK kinase that phosphorylates periplasmic binding proteins involved in the LAO (lysine, arginine, ornithine)/AO transport systems [64].

To investigate if the proteins identified in this study may be up-regulated by a common mechanism, the upstream regions of the corresponding 22 genes were analyzed using MEME [65]. A 17-bp palindromic motif was found upstream of 11 genes: $g y r A, \operatorname{gyr} B$, ssb, pprA, $d d r B$, $d d r D, \quad u v r D, \quad r e c A_{\mathrm{C}}, \quad \operatorname{rec} A_{\mathrm{P} 1}, \quad \operatorname{rec} A_{\mathrm{P} 3}$ and Deide_02842 (Type II restriction enzyme). This motif corresponds to the radiation/desiccation response motif (RDRM) first identified after analysis of radiation-induced genes in $D$. radiodurans and D. geothermalis [36]. In a previous study we scanned the entire genome of $D$. deserti with this motif and a match with the RDRM was found in the upstream region of 25 genes, including 10 of the 11 genes mentioned above [4]. Here, using another method (MEME), Deide_02842 is found as a new potential member of the RDRM regulon $[4,36]$. It has been shown that radiation-induced transcription of at least some of these RDRM-containing genes is dependent on PprI (IrrE) $[30,31,38]$. Besides the RDRM upstream of 11 genes, no other motifs were found for the up-regulated proteins identified here, and transcription of the other 11 genes may be regulated in different manners. Alternatively, accumulation of the corresponding proteins may not be related to up-regulated transcription but rather to an increase of their translation and/or to protein-protein or protein-DNA interactions that increase their stability.

We have shown that DdrB and SSB are clearly accumulating in large quantities in the very earliest stages after irradiation, at least in our experimental conditions. These two single-stranded DNA binding proteins are probably of high importance to protect ssDNA that is formed after massive DNA damage and/or to initiate genome reconstitution by recruitment of other DNA repair proteins. That they are both up-regulated at the same early stage may indicate that they work concomitantly. Interestingly, $\mathrm{Xu}$ et al. [19] have recently shown that both proteins interact in vitro. Another recent study reported that DdrB is involved in DNA repair through a single-strand annealing (SSA) process that precedes the Extended Synthesis-Dependent Strand Annealing (ESDSA) [12]. Finally, the specific post-translational modifications of GyrA detected from irradiated samples raises the importance of post-translational modifications of the Deinococcus proteome upon DNA damages. Whether the resulting heterogeneity impacts the cellular response is an open question.

\section{Materials and methods}

\section{$D$. deserti cellular growth and irradiation conditions}

D. deserti strain VCD115 [1] was grown in 10-fold diluted tryptic soy broth (TSB/10) supplemented with trace elements [32]. To prevent other fluctuations than the irradiation, pre- and post-irradiation incubation was performed under conditions similar to the irradiation ones, i.e. $20^{\circ} \mathrm{C}$ and without vigourous shaking. Two independent $1 \mathrm{~L}$ cultures were grown to exponential phase $\left(\mathrm{OD}_{600} 0.4\right)$ and exposed to $3 \mathrm{kGy}$ of gamma rays (39 Gy/min, ${ }^{60}$ Co source; CEA Cadarache, France). This resulted in $68 \%$ survival as determined by plating of serial dilutions and colony-forming unit counting. Samples of $100-150 \mathrm{ml}$ for proteome analysis were taken immediately before irradiation and at different time points after irradiation. Cells were harvested by centrifugation, washed twice with $50 \mathrm{mM}$ Tris $-\mathrm{HCl} \mathrm{pH} \mathrm{8.0,} \mathrm{frozen} \mathrm{in}$ liquid nitrogen and stored at $-80^{\circ} \mathrm{C}$. Culture samples $(5 \mathrm{ml})$ were also taken for pulsed-field gel electrophoresis (PFGE) analysis. PFGE analysis of genome reconstitution was performed as described [4].

\section{D. deserti protein extracts}

For each condition, cells ( $0.2 \mathrm{~g}$ of wet material) were resuspended in $3 \mathrm{~mL}$ of lysis buffer consisting of $8.75 \mathrm{M}$ urea, 2.5 M thiourea, $50 \mathrm{mM}$ DTT, $25 \mathrm{mM}$ spermine, and 5\% CHAPS, and containing a protease inhibitor cocktail (Complete Mini) from Roche (1 tablet per sample). Cells were disrupted with an ultrasound Vibracell 75042 sonicator (Fisher Bioblock Scientific) for $35 \mathrm{sec}$ (7 cycles of $5 \mathrm{sec}$ pulse and $5 \mathrm{sec}$ pause). The extracts were 
then ultracentrifuged for $1 \mathrm{~h}$ at $100,000 \mathrm{~g}$ at $4^{\circ} \mathrm{C}$ to remove cellular debris. Protein concentration from the supernatants was determined by a Bradford assay (Biorad) using Bovine Serum Albumin as a standard after diluting the samples to perform the assay below the limit of $4 \mathrm{M}$ urea.

\section{2-D electrophoresis and image analysis}

Because we followed several points along the time course after irradiation, only two independent biological replicates were performed. Because numerous biological replicates are difficult to perform regarding the radiation facilities used, specific effort in term of technical replicates has been done especially for time-points before irradiation and right after (0,2 and 4 hours) with 4 gels done per biological replicate for these time-points while 2 gels were done per biological replicate at 6, 8, 22 and 30 hours, resulting in a total of 48 gels for the whole analysis. Immobilines $18 \mathrm{~cm}$ Drystrips $\mathrm{pH}$ 3-10 (GE Healthcare) were rehydrated overnight with $300 \mu \mathrm{g}$ of protein extract. Isoelectric focusing was performed with a Multiphor system (GE Healthcare) up to $60 \mathrm{kVh}$. After focusing, separation strips were equilibrated for $15 \mathrm{~min}$ in $50 \mathrm{mM}$ Tris- $\mathrm{HCl}$ buffered at $\mathrm{pH} 8.8$ and containing 6 $\mathrm{M}$ urea, $30 \%$ glycerol, and $10 \mathrm{mg} / \mathrm{ml}$ dithiothreitol to disrupt disulphide bridges. The reduced thiols were then alkylated with $25 \mathrm{mg} / \mathrm{ml}$ iodoacetamide in the same buffer for $15 \mathrm{~min}$. The second dimension was performed using $12 \%$ acrylamide gels in Protean II xi 2-D cell (Biorad) at $25 \mathrm{~V}$ for $1 \mathrm{~h}$ then at $12.5 \mathrm{~W} /$ gel. The gels were first fixed in 5\% acetic acid and 30\% ethanol overnight, washed 3 times in $\mathrm{H}_{2} \mathrm{O}$ for $10 \mathrm{~min}$, treated with $0.02 \%$ sodium thiosulphate for $1 \mathrm{~min}$, and then rinsed twice with $\mathrm{H}_{2} \mathrm{O}$ for $1 \mathrm{~min}$. The gels were stained overnight with Coomassie Brilliant Blue G250 (Biorad) and then rinsed twice with distilled water. These gels were scanned using an Umax Scanner (Pharmacia) at $600 \mathrm{dpi}$. Image analysis was performed using ImageMaster 2D Platinum v5.0 (GE Healthcare). The protein content of each spot was determined by its relative volume compared with the sum of all spot volumes in the gel, and expressed as a percentage of volume $(\% \mathrm{Vol})$. The replicated gels corresponding to the same time point were grouped in the same class. Statistical analysis was performed on individual sample classes, the control class comprising gels where unirradiated samples were resolved. Class ratios above 1.5 (meaning 1.5 fold change compared with control) were selected, t-test controlled $(\mathrm{p}<0.05)$, and the differences were examined visually prior to identification by MS. For the $2 \mathrm{DE}$ reference map, protein spots were identified by peptide mass fingerprint using a Biflex IV mass spectrometer (Bruker Daltonics). Some faint spots were identified by tandem mass spectrometry done with an Esquire ion trap
(Bruker Daltonics) coupled to an Ultimate ${ }^{\mathrm{TM}}$ NanoLC system (Dionex-LC Packings). For the time-course experiment, protein spots were identified by tandem mass spectrometry done with an LTQ-Orbitrap XL (Thermo) mass spectrometer.

\section{Hierarchical clustering analysis (HCA)}

HCA was used to group proteins with similar expression profile and help for visual selection of interesting clusters as described [66]. To this end, the complete \%Vol matrix from image analysis was logged-ratio transformed (i.e. each protein profile centered on its mean value after being logged) and imported in the PermutMatrix software [67]. HCA was then processed according to the Pearson distance and the Ward aggregation procedure to construct the resulting dendrogram and to allow heat map visualization of the clustered data matrix [66]. Only clusters with interesting profile regarding reconstitution of intact DNA molecules, i.e. those with spots intensity clearly increasing during the early time-course experiment (time 2, 4, 6 and $8 \mathrm{~h}$ post irradiation), were selected. The corresponding spots were manually controlled for missing values and/or bad alignments so that false positive detection was reduced.

\section{In-gel trypsin digestion}

2-DE protein spots were excised from gels and treated as previously described [43]. They were trypsin digested using the Montage In-Gel DigestZP Kit (Millipore). The resulting peptides were analysed either by Matrix-Assisted Laser Desorption Ionisation - Time Of Flight (MALDITOF) MS or nano-liquid chromatography coupled to tandem mass spectrometry (nanoLC-MS/MS).

\section{Maldi-tof MS}

A Biflex IV mass spectrometer (Bruker Daltonics) was used in reflectron mode for MALDI-TOF MS analysis of peptides and mass fingerprint identification of proteins. A saturated solution of $\alpha$-cyano- 4 hydroxycinnamic acid prepared in acetonitrile:water $1: 1$ with $0.1 \%$ trifluoroacetic acid was $1 / 4$ diluted in the same solvent, and used as a matrix. Peptide and matrix solution were spotted on a stainless steel plate and air-dried. Calibration was done using a standard peptide mixture (Peptide Calibration Standard) from Bruker Daltonics as previously described [68]. Spectra were acquired over the $500-3500 \mathrm{~m} / \mathrm{z}$ range by accumulating spectra from at least 100 shots, with ion extraction mode using an accelerating voltage of $19 \mathrm{kV}$ and an extraction delay of $0.2 \mathrm{~ns}$. Peptide mass fingerprints were analysed using the Mascot software version 2.2 (Matrix Science) and a local database comprising 3,455 D. deserti protein sequences totalling 980,690 amino acids [4]. The maximum number of miss-cleavages was set at one. Carbamidomethylation of 
cysteines was set as fixed modification and oxidation of methionines as variable modification. Protein identification reliability was evaluated on the basis of the probability-based Mowse score $(\mathrm{p}<0.05)$, mass error, number of peptides matches and similarity of experimental and theoretical protein molecular masses and isoelectric points.

\section{NanoLC-MS/MS}

NanoLC-MS/MS was done either with an Esquire ion trap (Bruker Daltonics) coupled to an Ultimate ${ }^{\mathrm{TM}}$ NanoLC system (Dionex-LC Packings) or an LTQ-Orbitrap XL instrument (Thermo) coupled to an Ultimate 3000 LC-system (DionexLC Packings). In the former case, the instrument was controlled by HyStar TM software and on-line connected with a PepMap C18 nanocolumn (75 $\mu \mathrm{m} \times 150$ LC Packings). Samples $(20 \mu \mathrm{L})$ were injected and separated with a $30 \mathrm{~min}$ linear gradient. The gradient was achieved from $5 \%$ solvent A (95:5 $\left.\mathrm{H}_{2} \mathrm{O} / \mathrm{ACN} 0.1 \% \mathrm{Fa}\right)$ to solvent $50 \% \mathrm{~B}\left(20: 80 \mathrm{H}_{2} \mathrm{O} /\right.$ ACN $0.1 \% \mathrm{FA}$ ) at a flow rate of $20 \mathrm{nl} / \mathrm{min}$. Eluted peptides were electro-sprayed into the nano-ESI source of an Esquire 3000 Plus (Bruker). Spray voltage was set at $2000 \mathrm{~V}$ and capillary temperature at $170^{\circ} \mathrm{C}$. The ion trap was operated in data-dependent MS to MS/MS switching mode using various precursors detected in the $100-2000 \mathrm{~m} / \mathrm{z}$ unit window, scan resolution $13000 \mathrm{~m} / z$ per second, selected using a 3 $\mathrm{m} / \mathrm{z}$ unit ion isolation window and excluding single charged ions. Data were processed with the DataAnalysis software (Bruker Daltonics). Mgf files were searched against the $D$. deserti protein sequence local database using MASCOT 2.2 software (MatrixScience). MASCOT search parameters used with MS/MS data were similar as for those described above except: peptide tolerance at $0.4 \mathrm{Da}, \mathrm{MS} / \mathrm{MS}$ tolerance at 0.4 $\mathrm{Da}$, peptide charge at $+1 /+2 /+3$. Only peptides on rank 1 with an ion score above 30 were selected. Proteins identified by at least 2 different peptides were validated. Otherwise, LC-MS/MS experiments were performed on a LTQOrbitrap XL hybrid mass spectrometer (ThermoFisher) coupled to a UltiMate 3000 LC system (Dionex-LC Packings) in conditions similar as those previously described [69]. Briefly, peptide mixtures (0.1-2 pmol) were loaded and desalted online in a reverse phase precolumn Acclaim Pepmap $100 \mathrm{C} 18$ (5 $\mu \mathrm{m}$ bead size, $100 \AA$ pore size, $5 \mathrm{~mm} \times$ $300 \mu \mathrm{m})$ from LC Packings. They were resolved on a nanoscale Acclaim Pepmap 100 C18 (3 $\mu \mathrm{m}$ bead size, $100 \AA$ pore size, $15 \mathrm{~cm} \times 75 \mu \mathrm{m}$ ) from LC Packings at a flow rate of 0.3 $\mu \mathrm{L} / \mathrm{min}$. Peptides were separated using a $30 \mathrm{~min}$-gradient (5 to $60 \%$ solvent $\mathrm{B})$ with aqueous solvent $\mathrm{A}(0.1 \% \mathrm{HCOOH})$ and solvent $\mathrm{B}\left(0.1 \% \mathrm{HCOOH} / 80 \% \mathrm{CH}_{3} \mathrm{CN}\right)$. The column was then washed for 10 min with $100 \% \mathrm{~B}$ and reequilibrated for 20 min with $5 \%$ B. Full-scan mass spectra were measured from $\mathrm{m} / \mathrm{z} 300$ to 1800 . The LTQ-orbitrap $\mathrm{XL}$ mass spectrometer was operated in the data-dependent mode using the TOP5 strategy with a Fourier Transform
Mass Spectrometer (FTMS) resolution sets at 30,000 as previously reported [4]. In brief, a scan cycle was initiated with a full scan of high mass accuracy in the Orbitrap, which was followed by MS/MS scans in the linear ion trap on the 5 most abundant precursor ions with dynamic exclusion of previously selected ions. This dynamic exclusion consisted in two acquisitions of MS/MS spectra of the most abundant ion during a period of $30 \mathrm{sec}$ and then excluding this ion for the followed fragmentations during the next $60 \mathrm{sec}$. The activation type was collisional-induced dissociation with a standard normalized collision energy sets at 30 .

\section{Construction and radiation survival of $D$. deserti mutant strains}

The Deide_19260 deletion mutant was constructed using recently developed genetic tools for $D$. deserti [38]. Briefly, the mutant was obtained by allelic replacement via double homologous recombination after transformation of $D$. deserti wild-type with a plasmid construct derived from $E$. coli vector pUC19, which does not replicate in $D$. deserti. In this plasmid, one-kb fragments corresponding to DNA upstream and downstream of Deide_19260 were cloned in the correct orientation respectively upstream and downstream of a kanamycin resistance cassette. The latter was cloned as a BamHI-PstI fragment in pUC19. Expression of the kanamycin resistance gene in this cassette is driven by the constitutive promoter of the tuf gene (Deide_18970, encoding elongation factor EF-Tu). After three rounds of selection on plates containing $10 \mu \mathrm{g} / \mathrm{ml}$ kanamycin, diagnostic PCR to confirm double homologous recombination at the correct locus and complete absence of Deide_19260 was performed using appropriate primers. The Deide_19260 deletion mutant was called SF7. The Deide_20140 mutant, called SF8, was constructed in a similar way (but here the kanamycin cassette was present in pUC19 as a BamHI-XbaI fragment). All primer sequences are listed in Additional file 6: Table S3. Survival of mutants and wild-type after exposure to increasing doses of gamma (up to $10 \mathrm{kGy}$ ) or UV (up to $750 \mathrm{~J} / \mathrm{m}^{2}$ ) irradiation was determined as described [32].

\section{Additional files}

Additional file 1: Figure S1. Reference 2D electrophoresis gel map for exponential Deinococcus deserti VCD115 cells. This map was established for cells grown at $30^{\circ} \mathrm{C}$ and harvested at the exponential phase. From 863 clearly distinguishable Coomassie-stained spots, we selected 131 spots among the most intense that could serve as landmarks. They are labelled on the figure and their characteristics reported in Additional file 2: Table S1.

Additional file 2: Table S1. List of proteins of the reference 2DE-gel map This table lists the 171 soluble polypeptides unambiguously identified from 137 spots selected among the most intense. We can note the presence of 20 hypothetical conserved proteins and two of them 
highly expressed (Deide_06180 and Deide_11730). The most abundant proteins appear in bold face.

Additional file 3: Figure S2. Post-irradiation growth of $D$. deserti. Additional file 4: Figure S3. Comparison between Deide_1p01260 \& Deide_3p00210 genes, and RecA $A_{C} \&$ RecAp polypeptides. Panel A shows the sequence of Deide_1p01260 and Deide_3p00210 open reading frames with identical nucleotides in black and differing nucleotides in red. These different nucleotides are all in the third position of the codon and are silent mutations. Panel $B$ shows the amino acid sequences of Rec $A_{C}$ (upper line) and RecAp (bottom line). Amino acids that are different in these sequences are in blue and red respectively. Proteotypic tryptic peptides detected by mass spectrometry are indicated with blue and red lines.

Additional file 5: Table S2. Comparison of radio-induced proteins of $D$. deserti with transcriptomics and proteomics data from $D$. radiodurans.

Additional file 6: Table S3. Primers.

\section{Abbreviations}

PFGE: Pulsed-Field Gel Electrophoresis; HCA: Hierarchical Clustering Analysis.

\section{Competing interests}

The authors declare that they have no competing interests.

\section{Authors' contributions}

$A D$ designed the experiments, analysed and interpreted the data, and drafted the manuscript. ES and PG recorded the proteomic and mass spectrometry data, and participated in the data interpretation. LB, SF and AdG prepared the microbial samples and performed the genetic experiments, BM performed the HCA analysis. AdG and JA conceived the study, participated in the data interpretation, drafted and revised the manuscript. All authors read and approved the final manuscript.

\section{Acknowledgements}

We gratefully acknowledge Eric Quéméneur and Thierry Heulin for constant support, as well as Véronique Malard for advices regarding preparation of protein extracts. We thank the Commissariat à l'Energie Atomique et aux Energies Alternatives and the Agence Nationale de la Recherche (ANR-07BLAN-0106-02) for financial support.

\section{Author details}

'Laboratoire de Biochimie des Systèmes Perturbés, CEA Marcoule, DSV, iBEB, SBTN, LBSP, BAGNOLS-SUR-CEZE F-30207, France. ${ }^{2}$ CEA, DSV, IBEB, Lab Ecol Microb Rhizosphere \& Environ Extrem (LEMiRE), Saint-Paul-lez-Durance F-13108, France. ${ }^{3}$ CNRS, UMR 6191, Biol Veget \& Microbiol Environ, Saint-Paul-lez-Durance F-13108, France. ${ }^{4}$ Aix-Marseille Université, Saint-Paul-lez-Durance F-13108, France. ${ }^{5}$ INRA, UR1213 Herbivores, Saint Genès Champanelle F-63122, France.

Received: 3 August 2012 Accepted: 23 December 2012 Published: 15 January 2013

\section{References}

1. De Groot A, Chapon V, Servant P, Christen R, Saux MF, Sommer S, Heulin T: Deinococcus deserti sp. nov., a gamma-radiation-tolerant bacterium isolated from the Sahara Desert. Int J Syst Evol Microbiol 2005, 55:2441-2446.

2. Mattimore V, Battista JR: Radioresistance of Deinococcus radiodurans: functions necessary to survive ionizing radiation are also necessary to survive prolonged desiccation. J Bacteriol 1996, 178:633-637.

3. Rainey FA, Ray K, Ferreira M, Gatz BZ, Nobre MF, Bagaley D, Rash BA, Park MJ, Earl AM, Shank NC, et al: Extensive diversity of ionizing-radiationresistant bacteria recovered from Sonoran Desert soil and description of nine new species of the genus Deinococcus obtained from a single soil sample. Appl Environ Microbiol 2005, 71:5225-5235.

4. de Groot A, Dulermo R, Ortet P, Blanchard L, Guerin P, Fernandez B, Vacherie B, Dossat C, Jolivet E, Siguier $P$, et al: Alliance of proteomics and genomics to unravel the specificities of Sahara bacterium Deinococcus deserti. PLoS Genet 2009, 5:e1000434.
5. Carroll JD, Daly MJ, Minton KW: Expression of recA in Deinococcus radiodurans. J Bacterio/ 1996, 178:130-135.

6. Gutman PD, Carroll JD, Masters Cl, Minton KW: Sequencing, targeted mutagenesis and expression of a recA gene required for the extreme radioresistance of Deinococcus radiodurans. Gene 1994, 141:31-37.

7. Repar J, Cvjetan S, Slade D, Radman M, Zahradka D, Zahradka K: RecA protein assures fidelity of DNA repair and genome stability in Deinococcus radiodurans. DNA Repair (Amst) 2010, 9:1151-1161.

8. Liu Y, Zhou J, Omelchenko MV, Beliaev AS, Venkateswaran A, Stair J, Wu L, Thompson DK, Xu D, Rogozin IB, et al: Transcriptome dynamics of Deinococcus radiodurans recovering from ionizing radiation. Proc Natl Acad Sci USA 2003, 100:4191-4196.

9. Edwards JS, Battista JR: Using DNA microarray data to understand the ionizing radiation resistance of Deinococcus radiodurans. Trends Biotechnol 2003, 21:381-382.

10. Narumi I: Unlocking radiation resistance mechanisms: still a long way to go. Trends Microbiol 2003, 11:422-425.

11. Tanaka M, Earl AM, Howell HA, Park MJ, Eisen JA, Peterson SN, Battista JR: Analysis of Deinococcus radiodurans's transcriptional response to ionizing radiation and desiccation reveals novel proteins that contribute to extreme radioresistance. Genetics 2004, 168:21-33.

12. Bouthier De La Tour C, Boisnard S, Norais C, Toueille M, Bentchikou E, Vannier F, Cox MM, Sommer S, Servant P: The deinococcal DdrB protein is involved in an early step of DNA double strand break repair and in plasmid transformation through its single-strand annealing activity. DNA Repair (Amst) 2011, 10:1223-1231.

13. Gutsche I, Vujicic-Zagar A, Siebert $X$, Servant $P$, Vannier $F$, Castaing B, Gallet B, Heulin T, de Groot A, Sommer S, Serre L: Complex oligomeric structure of a truncated form of DdrA: a protein required for the extreme radiotolerance of Deinococcus. Biochim Biophys Acta 2008, 1784:1050-1058.

14. Harris DR, Tanaka M, Saveliev SV, Jolivet E, Earl AM, Cox MM, Battista JR: Preserving genome integrity: the DdrA protein of Deinococcus radiodurans R1. PLoS Biol 2004, 2:e304.

15. Jolivet E, Lecointe F, Coste G, Satoh K, Narumi I, Bailone A, Sommer S: Limited concentration of RecA delays DNA double-strand break repair in Deinococcus radiodurans R1. Mol Microbiol 2006, 59:338-349.

16. Narumi I, Satoh K, Cui S, Funayama T, Kitayama S, Watanabe H: PprA: a novel protein from Deinococcus radiodurans that stimulates DNA ligation. Mol Microbiol 2004, 54:278-285.

17. Norais CA, Chitteni-Pattu S, Wood EA, Inman RB, Cox MM: DdrB protein, an alternative Deinococcus radiodurans SSB induced by ionizing radiation. J Biol Chem 2009, 284:21402-21411.

18. Sugiman-Marangos $S$, Junop MS: The structure of $D d r B$ from Deinococcus: a new fold for single-stranded DNA binding proteins. Nucleic Acids Res 2010, 38:3432-3440.

19. Xu G, Lu H, Wang L, Chen H, Xu Z, Hu Y, Tian B, Hua Y: DdrB stimulates single-stranded DNA annealing and facilitates RecAindependent DNA repair in Deinococcus radiodurans. DNA Repair (Amst) 2010, 9:805-812.

20. Cox MM, Battista JR: Deinococcus radiodurans - the consummate survivor. Nat Rev Microbiol 2005, 3:882-892.

21. Levin-Zaidman S, Englander J, Shimoni E, Sharma AK, Minton KW, Minsky A: Ringlike structure of the Deinococcus radiodurans genome: a key to radioresistance? Science 2003, 299:254-256.

22. Daly MJ, Gaidamakova EK, Matrosova VY, Kiang JG, Fukumoto R, Lee DY, Wehr NB, Viteri GA, Berlett BS, Levine RL: Small-molecule antioxidant proteome-shields in Deinococcus radiodurans. PLoS One 2010, 5:e12570.

23. Daly MJ, Gaidamakova EK, Matrosova VY, Vasilenko A, Zhai M, Leapman RD, Lai B, Ravel B, Li SM, Kemner KM, Fredrickson JK: Protein oxidation implicated as the primary determinant of bacterial radioresistance. PLOS Biol 2007, 5:e92.

24. Daly MJ, Gaidamakova EK, Matrosova VY, Vasilenko A, Zhai M, Venkateswaran A, Hess M, Omelchenko MV, Kostandarithes HM, Makarova KS, et al: Accumulation of $\mathrm{Mn}$ (II) in Deinococcus radiodurans facilitates gamma-radiation resistance. Science 2004, 306:1025-1028.

25. Blasius M, Sommer S, Hubscher U: Deinococcus radiodurans: what belongs to the survival kit? Crit Rev Biochem Mol Biol 2008, 43:221-238.

26. Armengaud: Systems biology and synthetic biology: understanding biological complexity on the critical path to personalized medecine. Curr Pharmacogenomics \& Personalized Medicine 2010, 8:257-267. 
27. Armengaud J: Proteogenomics and systems biology: quest for the ultimate missing parts. Expert Rev Proteomics 2010, 7:65-77.

28. Zhang C, Wei J, Zheng Z, Ying N, Sheng D, Hua Y: Proteomic analysis of Deinococcus radiodurans recovering from gamma-irradiation. Proteomics 2005, 5:138-143.

29. Lu H, Gao G, Xu G, Fan L, Yin L, Shen B, Hua Y: Deinococcus radiodurans Pprl switches on DNA damage response and cellular survival networks after radiation damage. Mol Cell Proteomics 2009, 8:481-494.

30. Earl AM, Mohundro MM, Mian IS, Battista JR: The IrrE protein of Deinococcus radiodurans $\mathrm{R} 1$ is a novel regulator of recA expression. J Bacteriol 2002, 184:6216-6224.

31. Hua Y, Narumi I, Gao G, Tian B, Satoh K, Kitayama S, Shen B: Pprl: a general switch responsible for extreme radioresistance of Deinococcus radiodurans. Biochem Biophys Res Commun 2003, 306:354-360.

32. Vujicic-Zagar A, Dulermo R, Le Gorrec M, Vannier F, Servant P, Sommer S, de Groot A, Serre L: Crystal structure of the IrrE protein, a central regulator of DNA damage repair in deinococcaceae. J Mol Biol 2009, 386:704-716.

33. Liedert C, Bernhardt J, Albrecht D, Voigt B, Hecker M, Salkinoja-Salonen M, Neubauer P: Two-dimensional proteome reference map for the radiationresistant bacterium Deinococcus geothermalis. Proteomics 2010, 10:555-563.

34. Tian B, Wang H, Ma X, Hu Y, Sun Z, Shen S, Wang F, Hua Y: Proteomic analysis of membrane proteins from a radioresistant and moderate thermophilic bacterium Deinococcus geothermalis. Mol Biosyst 2010, 6:2068-2077.

35. Griffiths E, Gupta RS: Identification of signature proteins that are distinctive of the Deinococcus-Thermus phylum. Int Microbiol 2007, 10:201-208

36. Makarova KS, Omelchenko MV, Gaidamakova EK, Matrosova VY, Vasilenko A, Zhai M, Lapidus A, Copeland A, Kim E, Land M, et al: Deinococcus geothermalis: the pool of extreme radiation resistance genes shrinks. PLoS One 2007, 2:e955.

37. Basu B, Apte SK: Gamma radiation-induced proteome of Deinococcus radiodurans primarily targets DNA repair and oxidative stress alleviation. Mol Cell Proteomics 2012, 11:M111-011734.

38. Dulermo R, Fochesato S, Blanchard L, de Groot A: Mutagenic lesion bypass and two functionally different RecA proteins in Deinococcus deserti. Mol Microbiol 2009, 74:194-208.

39. Bentchikou E, Servant P, Coste G, Sommer S: A major role of the RecFOR pathway in DNA double-strand-break repair through ESDSA in Deinococcus radiodurans. PLoS Genet 2010, 6:e1000774.

40. Bharat A, Jiang M, Sullivan SM, Maddock JR, Brown ED: Cooperative and critical roles for both $\mathrm{G}$ domains in the GTPase activity and cellular function of ribosome-associated Escherichia coli EngA. J Bacteriol 2006, 188:7992-7996.

41. Bjellqvist B, Hughes GJ, Pasquali C, Paquet N, Ravier F, Sanchez JC, Frutiger S, Hochstrasser D: The focusing positions of polypeptides in immobilized $\mathrm{pH}$ gradients can be predicted from their amino acid sequences. Electrophoresis 1993, 14:1023-1031.

42. Zhu K, Zhao J, Lubman DM, Miller FR, Barder TJ: Protein pl shifts due to posttranslational modifications in the separation and characterization of proteins. Anal Chem 2005, 77:2745-2755.

43. Baudet M, Ortet P, Gaillard JC, Fernandez B, Guerin P, Enjalbal C, Subra G, de Groot A, Barakat M, Dedieu A, Armengaud J: Proteomics-based refinement of Deinococcus deserti genome annotation reveals an unwanted use of non-canonical translation initiation codons. Mol Cell Proteomics 2010, 9:415-426.

44. Polevoda B, Sherman F: The diversity of acetylated proteins. Genome Biol 2002, 3:reviews0006.

45. Polevoda B, Sherman F: Nalpha -terminal acetylation of eukaryotic proteins. J Biol Chem 2000, 275:36479-36482.

46. Persson B, Flinta C, von Heijne $G$, Jornvall $H$ : Structures of N-terminally acetylated proteins. Eur J Biochem 1985, 152:523-527.

47. Bradshaw RA, Brickey WW, Walker KW: N-terminal processing: the methionine aminopeptidase and $\mathrm{N}$ alpha-acetyl transferase families. Trends Biochem Sci 1998, 23:263-267.

48. Tanaka S, Matsushita Y, Yoshikawa A, Isono K: Cloning and molecular characterization of the gene rimL which encodes an enzyme acetylating ribosomal protein L12 of Escherichia coli K12. Mol Gen Genet 1989 217:289-293.
49. Kuo MH, Allis CD: Roles of histone acetyltransferases and deacetylases in gene regulation. Bioessays 1998, 20:615-626.

50. Hwang CS, Shemorry A, Varshavsky A: N-terminal acetylation of cellular proteins creates specific degradation signals. Science 2010, 327:973-977.

51. Joshi B, Schmid R, Altendorf K, Apte SK: Protein recycling is a major component of post-irradiation recovery in Deinococcus radiodurans strain R1. Biochem Biophys Res Commun 2004, 320:1112-1117.

52. Servant $P$, Jolivet $E$, Bentchikou $E$, Mennecier S, Bailone A, Sommer S: The $\mathrm{ClpPX}$ protease is required for radioresistance and regulates cell division after gamma-irradiation in Deinococcus radiodurans. Mol Microbiol 2007, 66:1231-1239.

53. Neher SB, Villen J, Oakes EC, Bakalarski CE, Sauer RT, Gygi SP, Baker TA: Proteomic profiling of ClpXP substrates after DNA damage reveals extensive instability within SOS regulon. Mol Cell 2006, 22:193-204.

54. Pruteanu M, Baker TA: Controlled degradation by ClpXP protease tunes the levels of the excision repair protein UvrA to the extent of DNA damage. Mol Microbiol 2009, 71:912-924.

55. Burns WG, Sims HE: Effect of radiation type in water radiolysis. J Chem Soc, Faraday Trans 1 1981, 77:2803-2813.

56. Fredrickson JK, Li SM, Gaidamakova EK, Matrosova WY, Zhai M, Sulloway HM, Scholten JC, Brown MG, Balkwill DL, Daly MJ: Protein oxidation: key to bacterial desiccation resistance? ISME J 2008, 2:393-403.

57. Barak $\mathrm{R}$, Eisenbach $\mathrm{M}$ : Co-regulation of acetylation and phosphorylation of $\mathrm{CheY}$, a response regulator in chemotaxis of Escherichia coli. $J \mathrm{Mol}$ Biol 2004, 342:375-381.

58. Rudolph J, Tolliday N, Schmitt C, Schuster SC, Oesterhelt D: Phosphorylation in halobacterial signal transduction. EMBO J 1995 , 14:4249-4257.

59. Wolfgang M, Lauer P, Park HS, Brossay L, Hebert J, Koomey M: PilT mutations lead to simultaneous defects in competence for natural transformation and twitching motility in piliated Neisseria gonorrhoeae. Mol Microbiol 1998, 29:321-330.

60. Palchevskiy $V$, Finkel SE: Escherichia coli competence gene homologs are essential for competitive fitness and the use of DNA as a nutrient. J Bacteriol 2006, 188:3902-3910.

61. Lee YH, Chirikjian JG: Sequence-specific endonuclease Bgl I. Modification of lysine and arginine residues of the homogeneous enzyme. J Biol Chem 1979, 254:6838-6841.

62. Newman M, Lunnen K, Wilson G, Greci J, Schildkraut I, Phillips SE: Crystal structure of restriction endonuclease Bgll bound to its interrupted DNA recognition sequence. EMBO J 1998, 17:5466-5476.

63. Koch HG, Moser M, Muller M: Signal recognition particle-dependent protein targeting, universal to all kingdoms of life. Rev Physiol Biochem Pharmacol 2003, 146:55-94.

64. Celis RT, Leadlay PF, Roy I, Hansen A: Phosphorylation of the periplasmic binding protein in two transport systems for arginine incorporation in Escherichia coli K-12 is unrelated to the function of the transport system. J Bacteriol 1998, 180:4828-4833.

65. Bailey TL, Elkan C: Fitting a mixture model by expectation maximization to discover motifs in biopolymers. Proc Int Conf Intell Syst Mol Biol 1994, 2:28-36.

66. Meunier B, Dumas E, Piec I, Bechet D, Hebraud M, Hocquette JF: Assessment of hierarchical clustering methodologies for proteomic data mining. J Proteome Res 2007, 6:358-366.

67. Caraux G, Pinloche S: PermutMatrix: a graphical environment to arrange gene expression profiles in optimal linear order. Bioinformatics 2005, 21:1280-1281.

68. Gabant G, Augier J, Armengaud J: Assessment of solvent residues accessibility using three Sulfo-NHS-biotin reagents in parallel: application to footprint changes of a methyltransferase upon binding its substrate. J Mass Spectrom 2008, 43:360-370.

69. Clair G, Roussi S, Armengaud J, Duport C: Expanding the known repertoire of virulence factors produced by Bacillus cereus through early secretome profiling in three redox conditions. Mol Cell Proteomics 2010, 9:1486-1498.

doi:10.1186/1477-5956-11-3

Cite this article as: Dedieu et al:: Major soluble proteome changes in

Deinococcus deserti over the earliest stages following gamma-ray irradiation. Proteome Science 2013 11:3. 